From the cabinet tests there seems to be little doubt that two of the factors which contribute to activation are (1) prolongation of the period of flight through the mist; (2) increased persistence of droplets of the order of 10 microns in diameter.

This physical explanation of activation does not cover the whole of the facts. For example, the observation of Haller et $a .^{3}$ that pure sesamin at 0.2 per cent is capable of acting as an effective activator against the housefly, whereas certain allied substances fail, is not covered.

We have been able to show activation against Aëdes aegypti with pure sesamin and, as mentioned earlier, with desesaminized sesame oil. The occurrence of knockdown is also delayed by pure sesamin.

\begin{tabular}{|c|c|c|c|c|c|c|c|c|}
\hline \multirow{2}{*}{\multicolumn{3}{|c|}{ Insecticide }} & \multicolumn{5}{|c|}{ \% Knockdown (min.) } & Av. percentage \\
\hline & & & 2 & 4 & 6 & 8 & 10 & kill after \\
\hline Pyrethrins, & $0.05 \%$ & wt./vol.* & 2 & 40 & 95 & 100 & 100 & 36 \\
\hline Sesamin & $0.20 \%$ & wt./vol. $\}$ & 0 & 20 & 60 & 95 & 100 & $\mathbf{7 5}$ \\
\hline
\end{tabular}

When sesame oil, isobutylundecylenamide or lubricating oil is used in the spray formula, the resulting droplets after evaporation consist of a solution of pyrethrins in a medium which is considerably more viscous than that resulting from an unactivated spray. They are also less concentrated. It was originally thought that the higher viscosity and lower concentration of pyrethrins in the droplets (resulting from the activated spray) delayed the penetration of pyrethrins and so the occurrence of knockdown. However, this explanation does not account for the delaying effect shown by sesamin and so probably has little validity.

When a spray droplet evaporates, non-volatile insecticides persist as sub-microscopic particles, as may be shown by spraying a dyed oil and mechanically depositing the resulting mist after four minutes. A cloud of dye, unassociated with oil, is obtained. Under suitable conditions the particles which persist when using any of the activators mentioned here, except sesamin, are of the order of 1-10 microns, and within this range impaction occurs at lower velocities. It appears that there is an optimum final droplet size for securing a maximum kill. If the droplet is too small, impaction with the insect does not take place; whereas if it is too large, the toxic principle is rapidly lost from the air space by sedimentation. Here it may be noted also that, for a given activator content of the spray, the final droplet size will depend upon the size of the particles produced by the atomizer. Theoretically, therefore, it would be expected that for an atomizer giving a coarse spray a lower activator content would be required than for a fine spray, since after evaporation the coarse spray leaves a residual droplet which may be so large that it will be rapidly lost by sedimentation.

At the time of writing we have some evidence that activation becomes more apparent as the degree of atomization produced by the gun increases. Finally, it is perhaps worth emphasizing that only Aëdes aegypti has been employed in these tests, and that the conclusions may not hold good for other insects.

This work is being carried out under a grant from the Medical Research Council.

Weed, A., Soap, 14, No. 6, 133 (1938).

Eagleson, C., Soap, 18, No. 12, 125 (1942).

- Haller. La Forge and Sullivan, J. Econ. Ent., 35, 247 (1942).

\section{THE CEDAR TREE}

\section{By ALEXANDER L. HOWARD}

A LTHOUGH the cedar tree is not indigenous to Great Britain, it has been established so long and has become a peculiar and ornamental feature of our parks around country houses, churches, and rectories, and so much admired that its absence would be a grievous loss. It is safe to affirm that up to seventy years ago very many thousands of trees could be counted throughout the country. During this period many have been destroyed, blown, or cut down, and it would be difficult to count up to four figures the numbers which have been replanted. Unfortunately, in too many cases a little cedar tree was planted close to the house, the original owner failing to recognize that the time would come, and that soon, when the cedar tree would top the house, so that additional loss has been caused by so many fine trees of this character having to be sacrificed.

The cedar is reared with difficulty. Many years ago the capable gardener at Mill Hill School told me that it had taken him several years-I think from six to nine-before he had been able to raise one tree from the well-known Linnean cedars there. William Boutcher in "A Treatise on Forest Trees", dated 1776 , says :

"The way that was first practised for procuring their seed, was by splitting the cones length-ways through the centre, with a sharp piece of iron, and to pick them out with your fingers, which may be easily done, after the cones have been exposed some hours before a warm fire. Should the cones be two years old, they will emit their seed more freely than when just gathered, and the seed equally good.

"The best soil to raise these plants in, is that of a rich old cow pasture, which, if not naturally of a light quality, must be mixed with a fourth or fifth part of sea-sand, or that taken from the sides of rivulets, to be well blended together for some months, before it is used. I have already mentioned that this tree will not require any attention after it has arrived to the age of three or four years, nor is it very delicate from the beginning; yet at the same time, it is absolutely necessary to give them abundant nourishment at first, in order to raise a fair and vigorous plant ; for if they once become dwarfish, stunted, or to lose their leading shoot, no art will be possible ever afterwards to restore them to a good figure."

Strutt says, in 1830, while mentioning that the cedar has not been much cultivated in England until of late years :

"its quick growth and its capability of thriving in a meagre soil, renders it peculiarly desirable for those bleak and barren situations which have hitherto been prineipally devoted to the fir. The frequent and solemn allusions to the Cedar in Holy Writ, seem to give it something of a sacred character; which is increased by a knowledge of the esteem in which it was held by the ancients, on account of its fragrant scent, its incorruptible nature, and above all its durability, insomuch that it is recorded that in the Temple of Apollo at Utica, there was found timber of Cedar nearly 2,000 years old."

From the financial aspect, no satisfactory result can be expected, and suitable sites for planting will be increasingly difficult to find. Only an enthusiastic desire on the part of those who might be able to re-afforest the country with this noble tree can prevent its final disappearance.

There is only one true cedar.

Quoting from "Timbers of the World" : 
"Under this commercial name (cedar) a motley collection of woods is included. In the first place comes the true cedar, a coniferous genus, Cedrus, of which there are three species or varieties : the cedar of Lebanon, the deodar, and the Mount Atlas cedar. Another coniferous type, the Port Orford cedar (Cupressus Lawsoniana), should more correctly be termed a cypress, for the tree is familiar in gardens under the name of Lawson's cypress. The pencil cedars, being the wood of several American species of Juniperus, are truly junipers and likewise conifers. All these woods possess a very fragrant scent. It is not surprising that the name cedar has popularly, and hence commercially, been attached to the cigar-box, a West Indian wood derived from a tree (Cedrela odorate) which is in no way allied to Cedrus but is a member of the mahogany family (Meliacea $\theta$ ). Other species of Cedrela, including the Indo-Australian $C$. Toona and $C$. australis and the Paraguayan cedar $C$. braziliensis, are more or less fragrant and receive the name cedar.

"The wood of Cedrela in many respects resembles mahogany, and has to some extent similar characteristics, so that the name has been extended to various American, African, etc., woods, which more or less resemble in appearance those of Cedrela, though not necessarily possessing any fragrance or strong scent. Some of the woods belong to the mahogany family, some do not, while the sources of still others are unknown. Then again there is in British and Dutch Guiana the so-called cedar, the product of Protium altissimum. The tree is not a cedar, nor has it any of the characteristics, and it is entirely without the fragrant scent usually associated with that wood.

"Further confusion arises owing to the fact that between mahogany and cedar woods of the Cedrela type there exist transitional forms, which are termed mahoganies or cedars according to the will of the vendor."

There are three different kinds of true cedars belonging to the genus Cedrus. The differences between them are so slight and fluctuating that all three are frequently included under one botanical name, C. Libani; sometimes, however, each is given a separate name. All are mountain trees ; the firstnamed growing on Mount Lebanon, in Cyprus, and the Orient; the second being Himalayan, and the third African and growing on the Atlas Mountains. All these are grown in English gardens. The timbers of the three kinds are almost indistinguishable. An easy way of identifying the varieties has been mentioned to me, though it should be taken as general and not absolute: L. for Libani, 1. for level (the branches extend from the tree in a more or less horizontal manner); D. for Deodar, d. for drooping (the branches generally droop); A. for atlantica, a. for ascending (the branches generally slope upwards).

Besides the references to cedar wood in the Bible, and in the earliest Greek and Roman writings in their poetry and prose, Pliny says :

"As for Cedars, the best simply be those that grow in Candie, Affricke, and Syria. This virtue hath the oil of Cedar, that if any wood or timber be throughly anointed therewith, it is subject neither to worm nor moth, ne yet to rottenness. The Juniper hath the same properties that the Cedar. They prove in Spain to be exceeding big and huge, the berries also greatest of all others. And wheresoever it groweth, the heart thereof is more found than the Cedar. . . .

... "the kings of Egypt and Syria, for default and want of Fir, have used (by report) instead thereof Cedar wood about their shipping. And verily the voice goeth of an exceeding big one which grew in Cyprus, and was cut down for a mast to serve that mighty galleace of king Demetrius, that had eleven bankes of oares to a side; a hundred and thirty foot it was high, and three fatham thick. And no marvel, since that the pirates and rovers who haunt the coasts of Germanie, make their punts or troughs of one entire piece of wood and no more, wrought hollow in manner of a boat, and some one of them will hold thirty men."

Although we have evidence that some of the wood of the true cedar was actually used, it is probable that by far the greater number referred to other scented woods. No greater confirmation of the above confusion over the name can be advanced than the interesting and informative remarks contained in Pliny's Discourse. He says :

"The great Cedar, called by the Greekes Cedrelate, as one would say, the Fir-Cedre, yieldeth a certain pitch or paraffin named Cedria, a singular medicine for the tooth. ache ; for it breaketh them, fetcheth them out of the head and easeth all their pain. ... This kind of pitch were excellent for the eyes but for one discommoditie, in that it causeth headache. It preserveth dead bodies from corruption, a world of years : contrariwise, living bodies it doth purifie and corrupt. A strange and wonderful propertie, thus to mortifie the quicke, and quicken (as it were) the dead. It marreth and rotteth apparell, as well linnen as woollen : and it killeth all living creatures."

\section{And further :}

"Also the Phœenicians have a lesse kind of Cedars much like to the Juniper; and two sorts there be thereof, the Lycian and the Phœnician, which differ in the leafe: for that which hath an hard, sharpe, and prickie leafe, is called Oxycedrus : full of branches it is besides, and so knurrie, that it is troublesome to the hand. As for the other Cedar, it hath an excellent smell. . . And the timber of it is everlasting: wherefore in old time they were wont to make the images of the gods, of this wood, as it appeareth by the statue of Apollo Sofianus, made of Cedar wood, brought from Seleucia. In Arcadia there is a tree like the Cedar, but in Phrygia it is called a shrub."

We might be in doubt, since Pliny describes the tree, using the word "fir", but afterwards he speaks of "berries" and "fruit", which while it is a true description of the foliage, is not a description of the cones of cedar of Lebanon. It is possible that the translation from Pliny's Latin to our language explains the point, as Strutt in his "Sylva" sets all doubts at rest when he refers to cedar of Lebanon and further says :

"It entered largely into the construction of the most celebrated buildings of antiquity; and in the glorious Temple of Solomon it seems to have been recorded of it, as one of its proudest boasts, that 'all was Cedar ; there was no stone seen'.

Elwes says the cedar was introduced into England during the seventeenth century, and quotes Loudon "who held the Cedars at Chelsea mentioned .... in England". But he says further that Mr. Challis informed him that he counted 236 rings on the Hammersmith tree when fallen, which would date the introduction back to 1638. Strutt mentions the Hammersmith Cedar, which at the time he wrote measured $16 \mathrm{ft} .6$ in. in circumference at the ground, $59 \mathrm{ft}$. in height, and branches covering an area of $80 \mathrm{ft}$.

According to Dr. Hunter in his notes in Evelyn's "Silva":

"The trees in the Apothecaries Garden at Chelsea were planted in 1683. In 1774 they had attained a circum. ference of $12 \frac{1}{2}$ feet at 2 feet from the ground, while their branches extended over a circular space 40 feet in diameter. 27 years afterwards the trunk of the largest one had increased more than $\frac{1}{2} \mathrm{ft}$. in circumference : this shows the quickness of its growth in proportion to that of the Oak, which in the same period would probably not have made half that progress." 


\section{Strutt says :}

"The Enfield Cedar stands in the garden of the Manor House, or old Palace in Enfield, the occasional retirement of Queen Elizabeth before she came to the throne, and the frequent scenes of her royal pleasures afterwards, in the early part of ber reign. In the year 1660 it became the residence of the learned Dr. Uvedale, master of the Grammar School of Enfield at that time, and famous for his curious gardens and choice collection of exotics. The Cedar, which is now perhaps the largest in the kingdom, was put into the ground by him, a plant brought direct from Mount Libanus. In 1779 it measured $14 \mathrm{ft} .6$ in. at the base, and $45 \mathrm{ft} .9 \mathrm{in}$. in height, $8 \mathrm{ft}$. of the upper part having been broken off by a high wind in 1703. The principal branches extended in length from the stem from 28 to $45 \mathrm{ft}$., and the contents of the tree, exclusive of the boughs, was about 293 cubic feet. In 1821, Dr. May, its present proprietor, and the master of the Grammar School at Enfield, took its measurement, which was as follows: $17 \mathrm{ft}$. in circumference at $1 \mathrm{ft}$. from the ground, $64 \mathrm{ft}$. in perpendicular height, and containing $548 \mathrm{cub}$. ft. of timber, exclusive of the branches, which from north-east to southwest extend $87 \mathrm{ft}$. and contain about $250 \mathrm{ft}$. of timber, making in the whole nearly $800 \mathrm{ft}$. of timber."

A remarkable cedar (Cedrus Libani) at Brockett Hall, in full vigour of life, measures $18 \mathrm{ft}$. in circumference, with fine healthy bark to the height of $20 \mathrm{ft}$., where it branches out with huge limbs. The total height is $80 \mathrm{ft}$. , and from the crown there are nine branches averaging $35 \mathrm{ft}$. long, each 4-5 ft. in circumference, giving a roof span of $62 \mathrm{ft}$. It is a beautiful specimen, having regard to its great age. At Brockett Hall there are 85-90 cedars in the Park, of which 45 or more are C. Libani, $2 C$. Deodara, and about $40 C$. atlantica.

The Rev. C. A. Johns gives an interesting account of the introduction of the cedar tree into France, as follows :

"Many years ago a Frenchman, who was travelling in the Holy Land, found a little seedling among the Cedars of Lebanon, which he longed to bring away as a memorial of his travels. He took it up tenderly, with all the earth about its little roots, and, for want of a better flowerpot, planted it carefully in his hat, and there he kept it and tended it.

"The voyage home was rough and tempestuous, and so much longer than usual, that the supply of fresh water in the ship fell short, and they were obliged to measure it out most carefully to each person. The captain was allowed two glasses a day, the sailors, who had the work of the ship on their hands, one glass each, and the poor passengers but half a glass. In such a scarcity you may suppose the poor Cedar had no allowance at all. But our friend the traveller felt for it es his child, and each day shared with it his small half glass of precious water ; and so it was, that when the vessel arrived at the port, the traveller had drunk so little water that he was almost dying, and the young Cedar so much that, behold, it was a noble and fresh little tree, six inches high !

"At the Custom-house the officers, who are always suspicious of smuggling, wished to empty the hat, for they would not believe but that something more valuable in their eyes lay hid beneath the moist mould. They thought of lace, or of diamonds, and began to thrust their fingers into the soil. But our poor traveller implored them so earnestly to spare his tree, and talked to them so eloquently of all that we read in the Bible of the Cedar of Lebanon, telling them of David's house and Solomon's temple, that the men's hearts were softened, and they suffered the young Cedar to remain undisturbed in its strange dwelling. From thence it was carried to Paris, and planted most carefully in the Jardin des Plantes. . . The Cedar grew larger and larger, and became the noblest tree there."
Those who have only seen cedars in England, or even been fortunate enough to have visited Mount Lebanon, can have no conception of the glory of these trees in the Himalayas. The late Sir George Hart, inspector-general of forests, made a wonderful collection of pictures, some of which I have. The wealth and magnificence of the cedars in the Himalayas is beyond description: the measurement of some is recorded by $J$. S. Gamble, who says of the deodar that it is the principal timber tree of the Himalayas, and quotes Thomson ("W. Him. and Tibet"), who mentions :

"One near Nachar on the Sutlej that had $35 \frac{1}{2} \mathrm{ft}$. in girth. Brandis mentions trees in Kunawar that had 30 to $36 \mathrm{ft}$. in girth ; Dr. Stewart measued one at Kuarsi, in the valley of the Ravi, that was $44 \mathrm{ft}$. at $2 \mathrm{ft}$. and $36 \mathrm{ft}$. at $6 \mathrm{ft}$. from the ground, and another was ascertained to be $34 \frac{1}{2} \mathrm{ft}$. in girth, and to be about 900 years old. Minniken records a tree at Punang in Bashahr that was $150 \mathrm{ft}$. high, and had a girth of over $36 \mathrm{ft}$., the clean bole height being $45 \mathrm{ft}$. The great section in the corridor of the Imperial Forest School at Dehra Dun shows $23 \mathrm{ft}$. in girth and 665 annual rings, equivalent to about 13 rings per inch of radius ; it came from the Gokul Forest in Tehri-Garhwal, and was cut by Mr. E. M. Moir. In the Moriru Forest in the Tehri-Garhwal Leased Forests, I measured in 1898 a stump-or rather shell, for the interior had decayedthat was $34 \mathrm{ft}$. in girth; while not far off, in Dumrali Block, a dry fallen tree was unearthed, $90 \mathrm{ft}$. long, and over $7 \mathrm{ft}$. in diameter at base. It had been dead for at least 100 years, and was, when it fell, probably 550 years old.... Aitchison mentions a tree in the Kuram Forests $22 \mathrm{ft}$. in girth and $150 \mathrm{ft}$. high. Schlich found a tree in the Sutlej Valley $240 \mathrm{ft}$. high; and W. R. Fisher tells me he saw one of $216 \mathrm{ft}$. in the Bashahr forests of the Pabar Valley."

From earliest times history continues to emphasize the high value placed on the tree and the wood of the cedar of Lebanon which the writings of the Greeks and Romans have handed down to posterity. The beauty of the tree is referred to over and over again in verse and prose, while the usefulness and durability, and the chemical properties, are emphasized. It is curious to notice that in spite of what was within our knowledge and that we have been familiar with the tree in Great Britain for three hundred years, the former of these qualities has been only partially recognized, while the latter has been entirely ignored.

The wood forms a good medium for decorative furniture and panelling. The preference shown by architects and principals unfortunately excludes twisted grain and sound knots, which being admitted give admirable character and variety to the finished work. The trees imported from North Africa and India contain less knots and twisted grain, thus producing a larger proportion of clean boards. All three varieties mixed show no apparent difference and are equally aromatic and durable.

The cedars in the Apothecaries Garden, referred to earlier, were made use of for the manufacture of three chairs for the use of the master and wardens of the Apothecaries Company, and are still in regular use. They were exhibited at the Empire Timber Exhibition at Holland Park in 1920, and were greatly admired by all who saw them.

The Rev. C. A. Johns says:

"the value of the timber of the Cedar, as a building material, is now thought to have been over-rated by the ancients. It is reddish white, with streaks, and does not seem to be much harder than deal. It is sweet-scented only for the first year after its being felled : it soon begins to shrink and warp, and is said to be by no means durable. But 
this is rather the character of English-grown Cedar than of timber which has come to maturity in its native moun. tains."

I do not find that I often differ from Johns, but in this case $I$ am afraid that he is quite wrong. The quality and durability of English-grown cedar is in every way as good as that produced elsewhere, and the aromatic scent is persistent-undeniable facts which can be proved.

The forests of cedars on Mt. Lebanon, which were known to the civilized world nearly two thousand years ago, have gone. The Rev. C. A. Johns, in 1849, quotes Maundrell as follows, who measured the largest cedar on Mt. Libanus :

"I found it 12 yards 6 inches in girth and yet sound, and 37 yards in the spread of its boughs."

To-day the traveller would have difficulty in counting a score still remaining. This is a terrible illustration of the destruction of forests with the march of civilization. From every quarter of the globe, whichever way we turn, we are confronted with the same story.

Dr. Fosdick, in a book entitled "A Pilgrimage to Palestine", says, speaking of the country between Samaria and Galilee, and the Plain of Sharon by the sea :

"Whether or not there used to be more trees upon these hills than now has often been discussed, but I do not see how anyone can doubt it. In this last war alone (19141918) it is estimated that 40 per cent of all the olive trees in Palestine were cut down for military purposes. To say nothing of the locusts, two great enemies of the trees have ravaged the land for centuries-Militarists and goats. . . . When Pompey came to take Palestine for Rome, the record says that he cleared away the trees, and Josephus tells us that Titus cut down every tree within ten miles of Jerusalem. ... Even in the Lebanons they are finding boundary stones set by Hadrian's foresters-I saw one in Beirut-where to-day only bare mountains remain. The forest of Hereth, where David hid, is gone; there is no forest of Bethal to shelter bears to-day; Kiriath-jearim, which means 'city of forests', would have no excuse now for such a name, and the woods of Sharon, which Strabo called 'a great forest', and which once stretched from the valley of Ajalon up to Mount Carmel, now have few relics of their ancient glory."

We should indeed be a decadent people if we allowed a thing of such beauty and interest as the cedar tree to vanish from our landscape.

\section{ANTIBACTERIAL SUBSTANCES IN GREEN PLANTS}

$\mathrm{F}$ ROM the earliest times, writes E. M. Osborn (Brit. J. Exp. Path., 24, 227; 1943), plants have been used in the attempt to cure disease. After giving a brief summary of recent work on the well-known occurrence of antibacterial substances in green plants, he records the results of his own investigation of about 2,300 different green plants, most of them flowering plants. All the plants used were freshly picked and all available parts of them were tested. The method of testing used was the diffusion method of Abraham and other Oxford workers (The Lancet, ii, 177 ; 1941), the antibacterial substance being tested against Staphylococcus aureus and Bacterium coli. The test shows only the presence or absence of the antibacterial substance and is not quantitative. A negative result does not necessarily prove the absence of the antibacterial substances, and the possibility of their destruction by enzymes must also be remembered.

At the time when this paper was written, antibacterial substances had been found in sixty-three genera of plants belonging to twenty-eight families. Extracts from plants belonging to the same families tend to show similar specificity and potency. Inhibiting substances are distributed throughout some plants (for example, Asarum europceum (Asarabacca)). In others their distribution is restricted. There is more of them in the seeds of Brassica oleracea (cabbage) than in other parts of this plant, and they were found only in the bark of Magnolia acuminata. This restricted distribution, together with differences in method of testing, may account for some negative results obtained with plants from which other workers have obtained bactericidal effects (for example, Chelidonium majus (greater celandine) and the turmip and horse radish). In many plants the inhibitory substances are produced by enzyme action ; for example, Plumeria bicolor, Cheiranthus cheiri (wall. flower) and Crepis taraxacifolia (hawk's-beard). In some instances the inhibitory substance is produced by the action of an enzyme situated in one part of the plant on an inactive precursor situated in another part of it. The drying of some plants causes loss of inhibitory power, for example, Clematis, Anemone, Ranunculus ; but the drying of others does not (for example, Crepis taraxacifolia (hawk's-beard), Reseda lutea (wild mignonette) and Asarum europoum). Certain well-known drug plants (Atropa, Datura, Digitalis) show no inhibitory power against the organisms used, nor do many plants recommended by herbalists.

A table shows the species from which "frankly positive" results were obtained. A feature of it is the activity of the Ranunculaceæ tested, some of which (for example, Anemone, Clematis, Helleborus and Ranunculus) inhibit both $\boldsymbol{S}$. aureus and Bact. coli. Extracts of some plants inhibit only $S$. aureus. Two of the plants tested were specific against Bact. coli. A full list of the species tested and the results obtained may be obtained from the Sir William Dunn School of Experimental Pathology, Oxford, and a similar list has been deposited in the archives of the Royal Society at Burlington House, London.

\section{FREQUENCY PERFORMANCE OF QUARTZ PLATES}

A $\mathrm{N}$ article by W. P. Mason (Bell Lab. Rec., 22, $A$ No. 6; February 1944) discloses some of the results of researches carried out to determine the frequency performance of quartz plates cut and oriented in a variety of ways. The natural frequencies depend largely on the plate dimensions and orientation with respect to the faces and angles of the original crystal, and on temperature.

Rectangular co-ordinates $x, y, z$, were used for specifying the manner of cutting. The $z$, or optical axis, runs vertically up the centre of the hexagonal prism assumed by the crystal ; the $y$, or mechanical, axis is taken perpendicular to any one of the three pairs of opposite faces ; and the $x$, or electrical, axis runs horizontally through opposite edges of the crystal. The first crystals used were known as $x$-cut and $y$-cut. Both have their width parallel to the 